\title{
Bacteriocin Occurrence and Activity in Escherichia coli Isolated from Bovines and Wastewater
}

\author{
Andrew Cameron ${ }^{1}$, Rahat Zaheer ${ }^{2} \mathbb{D}$, Emelia H. Adator ${ }^{3}$, Ruth Barbieri ${ }^{2}$, Tim Reuter ${ }^{4}(\mathbb{D}$ and \\ Tim A. McAllister $2, *$ (D) \\ 1 Faculty of Veterinary Medicine, University of Calgary, Calgary, AB T2N 4N1, Canada \\ 2 Lethbridge Research and Development Centre, Lethbridge, AB T1J 4B1, Canada \\ 3 Department of Food Science and Human Nutritional Sciences, University of Manitoba, \\ Winnipeg, MB R3T 2N2, Canada \\ 4 Alberta Agriculture and Forestry, Lethbridge, AB T1J 4V6, Canada \\ * Correspondence: tim.mcallister@canada.ca
}

Received: 24 July 2019; Accepted: 12 August 2019; Published: 15 August 2019

check for updates

\begin{abstract}
The increasing prevalence of antimicrobial resistant (AMR) E. coli and related Enterobacteriaceae is a serious problem necessitating new mitigation strategies and antimicrobial agents. Bacteriocins, functionally diverse toxins produced by most microbes, have long been studied for their antimicrobial potential. Bacteriocins have once again received attention for their role as probiotic traits that could mitigate pathogen burden and AMR bacteria in livestock. Here, bacteriocins were identified by activity screening and whole-genome sequencing of bacteriocin-producers capable of inhibiting bovine and wastewater $E$. coli isolates enriched for resistance to cephalosporins. Producers were tested for activity against shiga toxin-producing E. coli (STEC), AMR E. coli, and related enteric pathogens. Multiple bacteriocins were found in 14 out of 90 E. coli isolates tested. Based on alignment within BACTIBASE, colicins M, B, R, Ia, Ib, S4, E1, E2, and microcins V, J25, and H47, encoded by identical, variant, or truncated genes were identified. Although some bacteriocin-producers exhibited activity against AMR and STEC E. coli in agar-based assays, most did not. Despite this idiosyncrasy, liquid co-cultures of all bacteriocinogenic isolates with luciferase-expressing generic (K12) or STEC E. coli (EDL933) resulted in inhibited growth or reduced viability. These abundant toxins may have real potential as next-generation control strategies in livestock production systems but separating the bacteriocin from its immunity gene may be necessary for such a strategy to be effective.
\end{abstract}

Keywords: Escherichia coli; bacteriocin; colicin; microcin; antimicrobial peptide; antimicrobial resistance; cattle; wastewater; STEC

Key Contribution: Bacteriocinogenic E. coli capable of inhibiting multi-drug resistant E. coli were identified and characterized for bacteriocin production by whole-genome sequencing.

\section{Introduction}

Bacteriocins produced by the Gram-negative Enterobacteriaceae Escherichia coli are ribosome-synthesized toxins known as colicins and microcins [1]. Colicins are typically large proteins of high molecular mass (40-80 kDa), whereas microcins are low molecular weight $(<10 \mathrm{kDa})$ (poly)peptides [2,3]. Often produced exclusively under stress, such as the SOS response induced by mitomycin C [4], both colicins and microcins are capable of killing a narrow spectrum of competing E. coli and phylogenetically related bacteria [2]. A wide array of colicins and microcins have evolved numerous cytotoxic mechanisms, including include pore formation; degradation of peptidoglycan precursors; phosphatase activity; RNAse activity (often targeting 16S rRNA and specific tRNAs); and DNAse activity [2]. Producers are protected from self-killing by co-synthesizing a specific immunity protein which protects against the action of the bacteriocin through 
various mechanisms. Some $E$. coli solely produce the immunity factor to gain a competitive advantage against producers [5]. Colicins and microcins intrude into susceptible E. coli by exploiting conserved transport (i.e., frequently iron uptake systems [6]), diffusion, or efflux systems as specific receptors. The narrow target range of colicins is likely due to the requirement for specific outer membrane receptors on the cell surface. The method of colicin uptake in the inner membrane has given rise to a system of classification: In general, Group A colicins have parasitized the Tol system for translocation into E. coli and Group B colicins exploit Ton for translocation [2,7]. Indeed, the 'Tol' system is named for the fact that Tol mutants are 'tolerant' to colicins. Microcins may also be categorized into two groups depending on whether or not the microcin is post-translationally modified during maturation of the microcin peptide into the active form [3]. Group A and B colicins also differ in the way the colicin is released from the producer E. coli: Group A colicins typically encode a lysis protein thought to ensure the efficient and maximal release of colicin into the environmental milieu. Consequently, the release of Group A colicins is lethal to the producer E. coli cell [8]. Colicins have a functionally distinct modular domain structure: A translocation domain (N-terminal), a receptor-binding domain, and toxic domain (C-terminal) [2]. Some microcins have a modular design, featuring a toxic domain (N-terminal) and an uptake domain (C-terminal) [9]. These designs have likely facilitated the evolution of diverse toxicities via recombination.

Following nearly a century of extensive research, a great deal is known about the complexities of the molecular biology of E. coli bacteriocin function, immunity, and regulation [2]. Bacteriocin production has traditionally been an important factor in the selection of novel probiotic strains [10]. Although inhibition of pathogenic E. coli by bacteriocin-producers has been well-documented in vitro [2,11], their efficacy in vivo, as produced by live probiotics, has been less than stellar $[10,12,13]$. Relatively few studies have definitively characterized the ability of bacteriocin-producers to colonize and benefit the host: recent work has shown probiotic gastrointestinal colonization and efficacy remains controversial, transient, host-individualized, and limited [14]. Despite this, the administration of bacteriocin-producers in lieu of purified bacteriocins is thought to be a more effective approach than treatment with purified products [15]. To date, one of the only purified bacteriocins routinely used is nisin, a peptidyl bacteriocin discovered in the 1920s in the Gram-positive Lactococcus lactis subsp. lactis, which today is in large-scale usage as a food preservative [15]. Notwithstanding bacteriocins naturally produced in fermented food products, the exploitation of the plethora of known bacteriocins remains limited. However, as antimicrobial resistance (AMR) spreads and more countries limit the use of traditional antimicrobials, the need to develop alternative antimicrobials and pathogen mitigation strategies will grow. This requires the identification of novel bacteriocins, as well as rapid screening methodologies to search for putative bacteriocin-producers. Critically, it will be important to establish efficacy against pathogens likely to be already resistant to key antimicrobials, such as the $\beta$-lactam class drugs.

The first colicin was identified by Gratia in 1925, who called it 'principle $V^{\prime}$ ', a heat-labile microcin present in cultures of $E$. coli V (for 'virulent') now known most frequently as colicin V. Nearly a century later, it is evident that most bacterial species produce bacteriocins and nearly all living organisms produce antimicrobial peptides (AMPs) [3]. Bacteriocins have long been thought to be important elements in bacterial ecology and have been linked to both probiotic effects and virulence in E. coli $[16,17]$. The potential for bacteriocin-producing probiotics to serve as alternatives to antimicrobials, particularly in food animal species, has received increased attention in an era defined by increasing AMR [17,18]. Of concern for Enterobacteriaceae are extended-spectrum $\beta$-lactamases (ESBLs), which confer resistance to most $\beta$-lactam antimicrobials, including penicillins and cephalosporins. Human infections with ESBL-producing bacteria are associated with poor clinical outcomes $[19,20]$ and human illness due to infections with shiga toxin-producing E. coli (STEC) is a global health concern [21]. The development of bacteriocins or bacteriocinogenic probiotics capable of lowering the burden of AMR E. coli or excluding STEC in food animals could prevent zoonotic transmission of AMR E. coli and STEC. Fecal shedding of STEC O157:H7 and other serotypes in feedlot cattle is common [22]. Although probiotic colicinogenic E. coli strains have been found to exhibit activity against STEC in vitro [11], many probiotics have shown mixed results in reducing O157:H7 fecal shedding in cattle [12]. Moreover, bacteriocins produced by Gram-positive bacteria are not typically active against Gram-negative bacteria. Therefore, it is rational to conclude that Gram-negative bacteriocin-producers offer greater potential as probiotics against 
E. coli. The aim of this study was to identify putative bacteriocins capable of inhibiting both AMR E. coli and STEC. Given the increasing prevalence of AMR E. coli, we reasoned those same bacteria might harbor novel bacteriocins active against competing AMR E. coli. Here, by screening for evidence of the production of diffusible substances with anti-E. coli activity, we characterized the bacteriocin content of a library of $E$. coli isolated from bovine feces and wastewater via whole-genome sequencing.

\section{Results}

\subsection{Functional Screening and Genomic Identification of E. coli Bacteriocins}

A library of 90 E. coli (derived from bovine feces, feedlot-associated catchbasins, and wastewater influent) was treated with mitomycin $C$ and then tested for antimicrobial activity against E. coli K-12 strain MG1655 and the STEC O157:H7 strain EDL933. Of these, 14/90 isolates were observed to produce inhibition halos (i.e., diffusible substances) in lawns of MG1655, whereas only 4/14 produced halos in EDL933 lawns (Figure 1A). To confirm that inhibition was not due to phage activity in these isolates, serial dilutions of culture supernatants were spotted onto lawns of MG1655 and phage plaques were confirmed absent (not shown). These isolates, deemed putative 'bacteriocin-producers', were sequenced and their associated bacteriocins were identified bioinformatically by blastx alignment to BACTIBASE, a database of bacterial antimicrobial peptides. Bacteriocin genes were identified in all isolates, with some harboring as many as four unique bacteriocins (Table 1). Of those identified, the most abundant were colicins identical or near identical to colicins $B$ and $M$, which were found in up to 7/14 putative bacteriocin-producer $E$. coli. The next most common bacteriocins were close homologues or identical matches to colicin (microcin) $\mathrm{V}$ (found in 5/14 isolates), and colicins Ia and $\mathrm{Ib}$, which were each found in 2/14 isolates. Less frequent were the microcins H47 and J25 and colicins R, E1, E2, and S4.

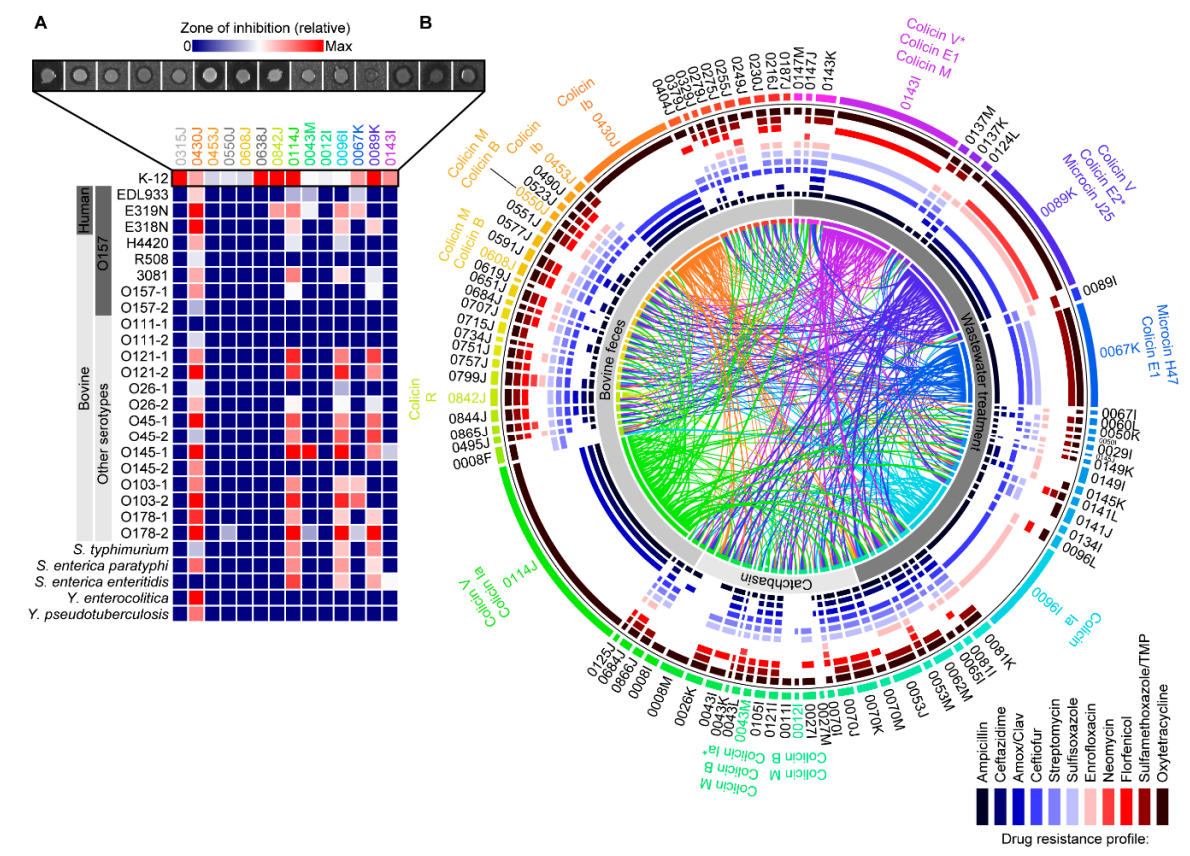

Figure 1. Activity of putative bacteriocin-producing E. coli against antimicrobial-resistant (AMR) E. coli, serotyped E. coli, and other enteric bacteria. (A) Zones of inhibition and an activity heatmap of putative bacteriocin-producing E. coli against human- and bovine-derived shiga toxin-producing E. coli (STEC), including O157:H7 and other STEC serotypes associated with food-borne disease and other enteric bacteria. (B) Circular plot showing activity against E. coli isolates from bovine feces, feedlot catchbasins, and wastewater influent. Bacteriocin-producers are labelled, and antimicrobial activity is indicated by a link directly terminating at the colored bar representing the susceptible isolate. The AMR profile is shown for each isolate. The width of each link indicates the relative inhibition halo produced by each bacteriocin-producing strain. Isolates are not shown if they neither inhibited nor were inhibited by any other $E$. coli. 
Table 1. Summary of bacteriocins identified in sequenced E. coli isolates.

\begin{tabular}{|c|c|c|c|c|c|c|}
\hline E. coli Isolate & $\begin{array}{l}\text { Isolation } \\
\text { Source }\end{array}$ & AMR Profile ${ }^{1}$ & AMR Genes² & $\begin{array}{l}\text { Bacteriocins } \\
\text { Identified }\end{array}$ & Contig BLAST $\mathrm{Hit}^{3}$ & $\begin{array}{l}\text { Accession } \\
\text { Numbers }\end{array}$ \\
\hline 0315J & Bovine feces & $\begin{array}{l}\text { AMP, AMXC, STR, } \\
\text { OXYT }\end{array}$ & $\mathrm{v}_{\operatorname{mac} A B}$ & $\begin{array}{c}\text { colicin } \mathrm{M}^{*} \text { colicin } \\
\mathrm{B} * \text { colicin } \mathrm{S} 4 \\
\text { colicin } \mathrm{V}\end{array}$ & $\begin{array}{c}\mathrm{M}, \mathrm{B} \text { S. enterica } \\
\text { Saintpaul } \\
\text { pCFSAN004174 } \\
\text { S4 pSYM12 } \\
\mathrm{V}_{\text {S. }} \text { enterica Kentucky } \\
\text { pCVM29188_146 }\end{array}$ & $\begin{array}{c}\mathrm{M}, \mathrm{B} C P 019207 \\
{ }^{\mathrm{S}} \mathrm{KM} 107848 \\
{ }^{\mathrm{V}} \mathrm{CP} 001122\end{array}$ \\
\hline 0430J & Bovine feces & $\begin{array}{c}\text { AMP, AMXC, CTZD, } \\
\text { CTIO, OXYT }\end{array}$ & ${ }^{\mathrm{Ib}}{ }_{b l a} a_{\mathrm{CMY}-2}{ }^{\mathrm{lb}}$ sugE & colicin Ib & $\begin{array}{c}\mathrm{Ib} \text { S. enterica } \\
\text { pFDAARGOS-312-4 }\end{array}$ & ${ }^{\mathrm{Ib}} \mathrm{CP} 022064$ \\
\hline 0453J & Bovine feces & $\begin{array}{l}\text { AMP, CTIO, SULF, } \\
\text { TMSZ, OXYT }\end{array}$ & & colicin Ib & ${ }^{\mathrm{Ib}} \mathrm{p} 2 \mathrm{HS}-\mathrm{C}-2$ & ${ }^{1 \mathrm{~A}} \mathrm{CP} 038182$ \\
\hline 0550J & Bovine feces & $\begin{array}{c}\text { AMP, CTIO, STR, } \\
\text { SULF, ENRO, FLOR, } \\
\text { OXYT }\end{array}$ & & colicin M colicin B & $\begin{array}{l}\text { M,B FHI82 plasmid } \\
\text { contig }\end{array}$ & M,B LM996773 \\
\hline 0608J & Bovine feces & $\begin{array}{l}\text { AMP, CTZD, CTIO, } \\
\text { STR, SULF, ENRO, } \\
\text { FLOR, TMSZ, OXYT }\end{array}$ & & colicin M colicin B & M,B p2013C-4404 & $\mathrm{M}, \mathrm{B} \mathrm{CP} 027378$ \\
\hline 0638J & Bovine feces & $\begin{array}{l}\text { AMP, AMXC, STR, } \\
\text { SULF, OXYT }\end{array}$ & & $\begin{array}{l}\text { colicin } \mathrm{M}^{*} \text { colicin } \\
\mathrm{B} * \text { colicin } \mathrm{V}\end{array}$ & $\begin{array}{l}\text { M,B p2013C-4404-2 } \\
\text { V pDSM30083 }\end{array}$ & $\begin{array}{l}\mathrm{M}, \mathrm{B} C \mathrm{CP} 027378 \\
{ }^{\mathrm{V}} \mathrm{CP} 033091\end{array}$ \\
\hline 0842J & Bovine feces & $\begin{array}{c}\text { AMP, AMXC, CTZD, } \\
\text { CTIO, STR, SULF, } \\
\text { FLOR, TMSZ, OXYT }\end{array}$ & & colicin R & ${ }^{R}$ p14408-3 & ${ }^{R}$ LT599828 \\
\hline 0114J & Bovine feces & $\begin{array}{l}\text { AMP, AMXC, CTZD, } \\
\text { FLOR, TMSZ, OXYT }\end{array}$ & & colicin V colicin Ia & V,Ia pCOV8 & V,1A MG648896 \\
\hline 0043M & $\begin{array}{l}\text { Feedlot } \\
\text { catchbasin }\end{array}$ & $\begin{array}{c}\text { AMP, AMXC, CTZD, } \\
\text { CTIO, STR, SULF, } \\
\text { FLOR, TMSZ, OXYT }\end{array}$ & M,B $\operatorname{aph}(6)-\mathrm{Id}$ & $\begin{array}{l}\text { colicin M, colicin } \\
\text { B colicin Ia * }\end{array}$ & $\begin{array}{l}\mathrm{M}, \mathrm{B} \text { S. enterica } \\
\text { Heidelberg } \\
\text { p12-4373-62 } \\
\text { Ia } 2014 C-3075\end{array}$ & $\begin{array}{l}\mathrm{M}, \mathrm{B} C P 012928 \\
{ }^{1 \mathrm{~A}} \mathrm{CP} 027448\end{array}$ \\
\hline 0012I & $\begin{array}{l}\text { Feedlot } \\
\text { catchbasin }\end{array}$ & STR, OXYT & $\operatorname{aph}(6)-I d$ tet $(C)$ & colicin M colicin B & M,B $\mathrm{pExPEC-XM}$ & $\mathrm{M}, \mathrm{B} C \mathrm{CP} 025329$ \\
\hline 0096I & $\begin{array}{l}\text { Wastewater } \\
\text { influent }\end{array}$ & AMP, CTIO, ENRO & & colicin Ia & ${ }^{\mathrm{Ia}} \mathrm{pLKSZ01}$ & ${ }^{1 \mathrm{~A}} \mathrm{CP} 030282$ \\
\hline 0067K & $\begin{array}{l}\text { Wastewater } \\
\text { influent }\end{array}$ & $\begin{array}{l}\text { AMP, CTIO, STR, } \\
\text { SULF, TMSZ, OXYT }\end{array}$ & & $\begin{array}{c}\text { colicin E1 } \\
\text { microcin H47 }\end{array}$ & $\begin{array}{l}\text { E1 pCOLE1-H22 } \\
{ }^{\mathrm{H} 47} \text { NCTC10444 }\end{array}$ & $\begin{array}{l}{ }^{\mathrm{E} 1} \text { AY913943 } \\
{ }_{\text {H47 LR134092 }}\end{array}$ \\
\hline 0089K & $\begin{array}{l}\text { Wastewater } \\
\text { Influent }\end{array}$ & $\begin{array}{l}\text { AMP, CTZD, CTIO, } \\
\text { ENRO, NMYN, OXYT }\end{array}$ & $\mathrm{E} 2, \mathrm{~J} 25 \mathrm{bmr} A$ & $\begin{array}{l}\text { colicin V colicin } \\
\text { E2 * microcin J25 }\end{array}$ & $\begin{array}{l}\mathrm{V}_{\mathrm{pAMSC}} \\
{ }_{\mathrm{E} 2,325} \mathrm{pH} 17-5\end{array}$ & $\begin{array}{c}\mathrm{V}_{\mathrm{CP}} 031107 \\
\mathrm{E} 2, \mathrm{~J} 25 \mathrm{CP} 021198\end{array}$ \\
\hline 0143I & $\begin{array}{c}\text { Wastewater } \\
\text { influent }\end{array}$ & $\begin{array}{l}\text { AMPI, CTIO, SULF, } \\
\text { FLOR, OXYT }\end{array}$ & ${ }^{\mathrm{M}, \mathrm{V}} b l a_{\mathrm{CTX}-\mathrm{M}-55}$ & $\begin{array}{l}\text { colicin E1 colicin } \\
\mathrm{M} \text { colicin } \mathrm{V}^{*}\end{array}$ & $\begin{array}{l}\text { E1 pEC276_KPC } \\
\text { M,V }\end{array}$ & $\begin{array}{c}{ }^{\mathrm{E} 1} \mathrm{CP} 018949 \\
\mathrm{M}, \mathrm{V}_{\mathrm{CP}} 035320\end{array}$ \\
\hline
\end{tabular}

${ }^{*}$ Truncated (potentially defective). ${ }^{1}$ Abbreviations: AMP, ampicillin; AMXC, amoxicillin-clavulanate; CTZD, ceftazidime; CTIO, ceftiofur; STR, streptomycin; SULF, sulfisoxazole; ENRO, enrofloxacin; NMYN, neomycin; FLOR, florfenicol; TMSZ, trimethoprim-sulfamethoxazole; OXYT, oxytetracycline. ${ }^{2}$ Antimicrobial resistance genes present on bacteriocin contigs.

${ }^{3}$ E. coli unless otherwise indicated; superscripts indicate bacteriocin and associated contig.

\subsection{Bacteriocins Identified, Genomic Context, and Similarity to Known Colicins and Microcins}

Except for microcin H47, all the bacteriocins identified were found on contigs aligning to plasmid sequences in the NCBI $n r$ database. Interestingly, several contigs aligned most closely ( $>95 \%$ nucleotide identity; highest query coverage) with plasmids found in various Salmonella enterica isolates (Table 1). However, individually, each bacteriocin aligned most closely with sequences from E. coli and many had identical amino acid (aa) sequences to their prototype bacteriocins (Figure 2). 


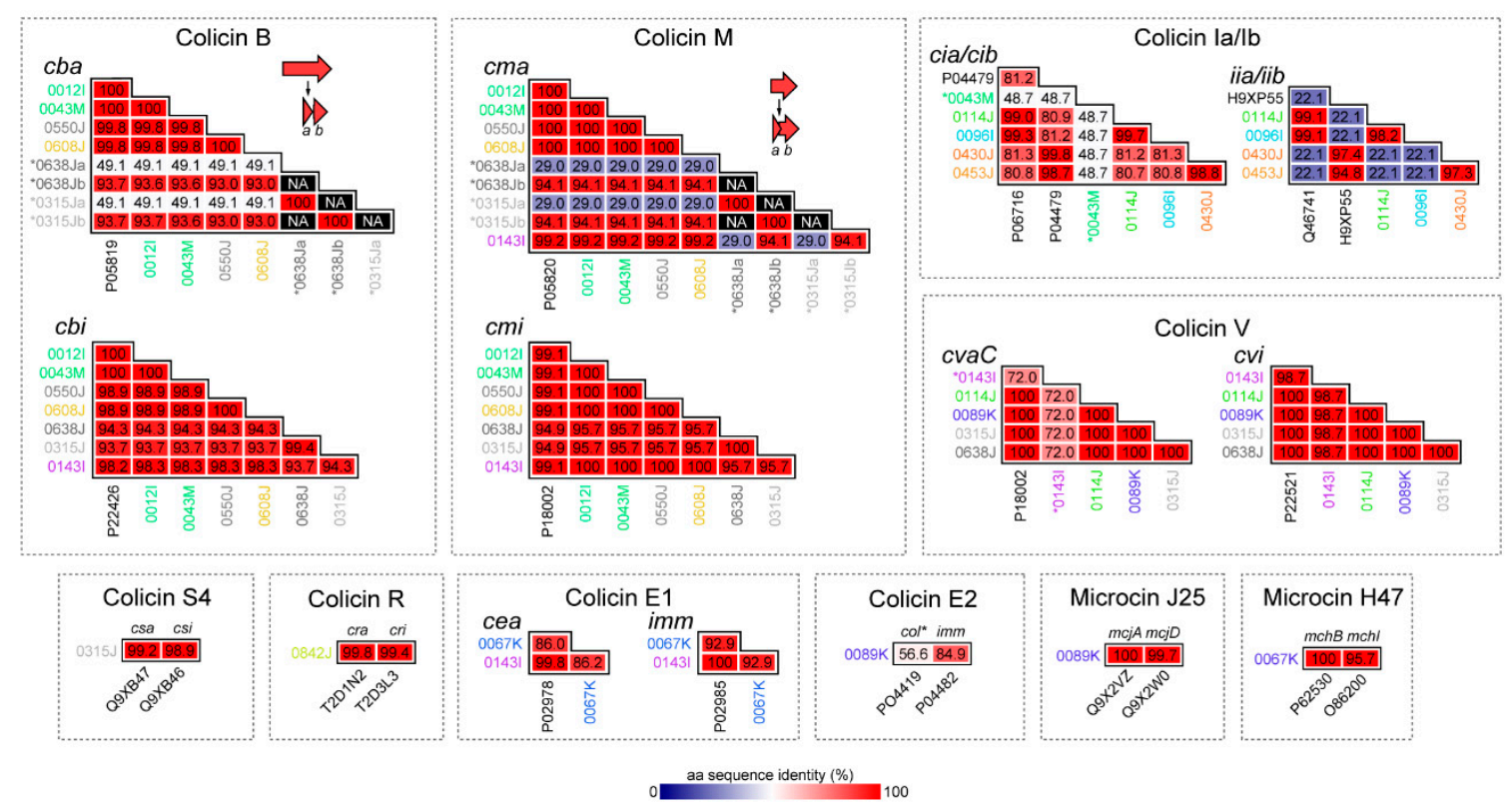

Figure 2. Summary of amino acid ( $a a$ ) identity of putative bacteriocins and cognate immunity genes identified in silico. Truncated genes are indicated with asterisks or shown as multiple arrows.

\subsubsection{Colicins $B$ and $M$}

Colicins B and M are 'Group B' colicins encoded by $c b a$ (colicin B activity gene) and $c m a$ (colicin $\mathrm{M}$ activity gene). The gene operons for colicins $\mathrm{B}$ and $\mathrm{M}$ are co-occurrent at frequencies greater than those expected by chance [23]. Here, each colicin was invariably found transcribed in the same direction and was adjacent to the cognate immunity genes, $c b i$ (colicin B immunity protein) and $c m i$ (colicin $\mathrm{M}$ immunity protein) (Figure 3). Without exception, the $c b i$ and $c m i$ immunity genes were found transcribed in the opposite direction to $c b a$ and cma. Consistent with the literature [2], no lysis proteins were associated with either colicin B or M, which otherwise were co-located on contigs containing genes involved in conjugal plasmid transfer or plasmid maintenance (e.g., tra genes, encoding conjugation proteins; spo0J, chromosome-partitioning protein; and parM, plasmid segregation protein). Colicins $\mathrm{B}$ and $\mathrm{M}$ were frequently associated with recombinases (e.g., xerD, tyrosine recombinase) and transposases. Consistent with this, contig BLASTs with the NCBI $n r$ database indicated the contigs containing colicin $\mathrm{B}$ and $\mathrm{M}$ had highest identity with self-transmissible plasmids originating either in E. coli or in Salmonella enterica (Table 1). Thus, the contig sequences containing colicin B and M described here are likely plasmid-borne. In isolates 0043M and 0012I, the contigs encoding colicin B and M carried aminoglycoside (aph(6)-Id) and tetracycline $(\operatorname{tet}(C))$ resistance genes. For isolate 0012I, the colicin-bearing plasmid is likely sufficient for the antimicrobial resistance phenotype (streptomycin; oxytetracycline) of the isolate.

A pore-forming colicin, Colicin B kills sensitive cells by forming ion channels that depolarize the cytoplasmic membrane. Structurally, colicin B does not have clearly delineated receptor-binding and translocation domains: The N-terminal (290 aa) contains both domains and the C-terminal contains the pore-forming domain. In isolates 0638J and 0315J, the $c b a$ (full length: $511 a a$ ) product was truncated with a premature termination codon into two putative fragments: The first fragment (94aa) had $49.1 \%$ $a a$ identity to the N-terminal of the cba prototype (UniProtKB: P08520) and the second (142 aa) had 93.7\% $a a$ identity to the C-terminal. The cognate immunity genes for the truncated $c b a$ shared $93.7-94.9 \% a a$ identity to the $c b i$ prototype (UniProtKB: P22426) vs. 99.8-100\% a a identity for the full-length $c b a$ genes. Likewise, the full-length colicin M cma identified here encoded for 271 aa proteins, except for isolates 0638J and 0315J, where the protein was truncated with a premature termination codon. Colicin M is regarded as the smallest of the colicins and is functionally unique, as it is the only colicin to inhibit 
peptidoglycan synthesis [24]. The cma gene containing a premature termination codon was annotated as two putative gene products: The first (N-terminal) fragment had low aa identity $(29.0 \%)$ to the $c m a$ prototype UniProtKB: P05820, whereas the second (C-terminal) had $94.1 \%$ aa identity. The cognate $\mathrm{cmi}$ immunity genes in these isolates were maintained but retained $94.9 \%$ a a identity to the $\mathrm{cmi}$ prototype (UniProtKB: P18002) vs. $99.1-100 \%$ a a identity when these isolates harbored full-length $c m a$ genes. Thus, the functionality of either cba or cma in isolates 0638J and 0315J is not clear. Furthermore, although colicin B was always co-located with colicin $\mathrm{M}$ in this collection, colicin $\mathrm{M}$ was found without colicin B in one instance and was instead contiguous with colicin $\mathrm{V}$ ( $c v a C$; truncated).

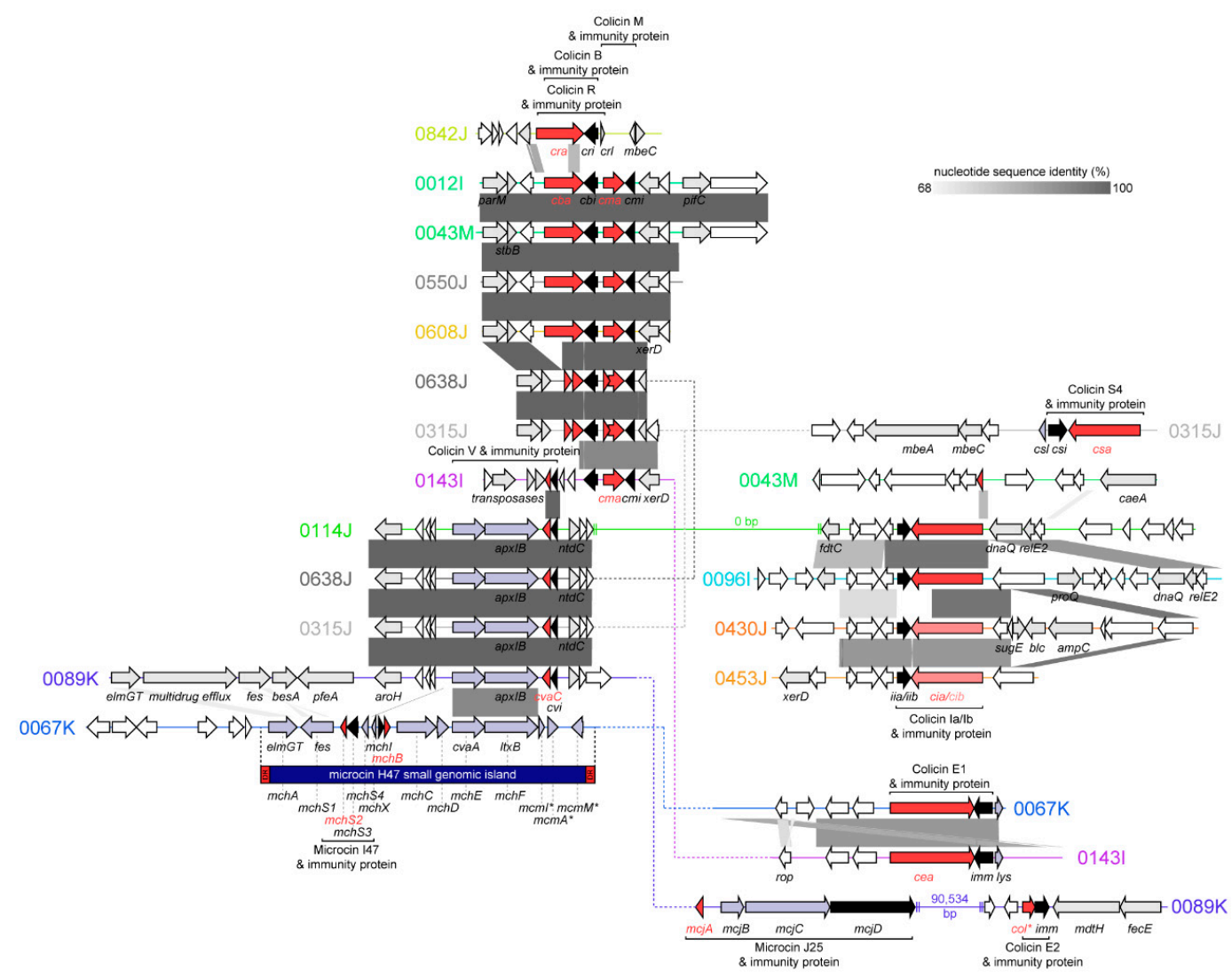

Figure 3. Linear comparisons of genomic loci encoding bacteriocins identified in silico in the genomes of putative bacteriocin-producing E. coli isolates. Amino acid (aa) sequence identity to prototype bacteriocins is shown. Truncated genes are indicated with asterisks or shown as multiple arrows. Potential genes are depicted as arrows showing bacteriocin genes (red), immunity genes (black), colicin-associated genes (light-blue), genes of known function (grey, labelled), and conserved hypothetical proteins (white). Solid lines (and $b p$ distance) indicate bacteriocin gene clusters found on the same contig; dashed lines indicate different contigs.

\subsubsection{Colicin S4}

Colicin S4 is a Group A colicin, which was detected in isolate 0315J harbored on a contig with identity (99\% nucleotide identity; $85.1 \%$ query coverage) to E. coli strain G1/2 plasmid pSYM12 (a component of the human probiotic product Symbioflor 2 [25]; GenBank: KM107848). Colicin S4 (encoded by $c s a$ ) is accompanied by both an immunity factor (csi) and a lysis protein (csl). In isolate 0315J, csa shares 99.2\% aa identity with the known csa sequence (UniProtKB: Q9XB47), and the immunity and lysis proteins share $98.9 \%$ and $100 \%$ a $a$ identity, respectively, to known sequences for csa and csl (UniProtKB: Q9XB46 and Q9XB46). 


\subsubsection{Colicin R}

The sole colicin gene in isolate 0842J was initially annotated as $c b a$, as the C-terminal (142 aa) of cra shared $68.3 \%$ a a identity with the equivalent sequence in $c b a$. However, the 0842J colicin gene had 99.8\% a identity to the colicin R activity gene cra (UniProtKB: T2D1N2), suggesting the colicin in 0842J and its cognate immunity and lysis proteins-cri and crl-comprise a variant of colicin $\mathrm{R}$, a 'group $\mathrm{A}^{\prime}$ Tol-dependent colicin. Colicin $\mathrm{R}$ was recently described and was found to be produced in biofilms formed by natural E. coli ROAR029 and exhibited increased activity against biofilm bacteria [26].

\subsubsection{Colicins Ia and Ib}

The Group B colicin Ia and its associated immunity protein are encoded by cia and iia, respectively. Colicin $\mathrm{Ib}$ and immunity protein are encoded by $c i b$ and $i i b$. Although the gene content and synteny of the colicinogenic loci in 0114J, 0096I, 0430J, and 0453J were similar, full-length variants of colicin Ia were found in isolates 0114J and 0096I, and variants of colicin Ib were found in 0430J and 0453J. The cib genes found in 0430J and 0453J were substantially different than cia, and shared only $80.8-81.3 \%$ aa identity to colicin Ia. A truncated remnant of cia which lacked iia was found in isolate 0043M, strongly suggesting colicin Ia in 0043M was nonfunctional. In isolates 0114J and 0096I, the cia and iia genes shared $99.0-99.3 \%$ a identity and $99.1 \%$ a identity to the colicin Ia and immunity gene prototypes (UniProtKB: P06716 and Q46741, respectively). The colicin Ib genes in 0430J and 0453J each shared 98.7-98.8\% a identity with the colicin Ib prototype (UniProtKB: P04479). Likewise, the immunity genes, designated $i i b$, shared $94.8-97.4 \%$ aa identity to the known colicin Ib immunity protein (UniProtKB: H9XP55). Interestingly, the cib immunity genes in 0430J and 0453J shared only $22.1 \%$ aa identity to iia. For both colicin Ia and Ib, all contigs identified matched various E. coli plasmids, and the contig harboring colicin $\mathrm{Ib}$ in isolate 0430J exhibited the highest identity $(99.9 \%$ nucleotide identity; $70.5 \%$ query coverage) to a plasmid found in a ground turkey S. enterica isolate (GenBank: CP022064.2). The $0430 \mathrm{~J}$ contig containing colicin Ib was notable for the presence of the ESBL bla ${ }_{\mathrm{CMY}-2}$, and $s u g E$, a determinant thought to confer resistance to quaternary ammonium compounds.

\subsubsection{Colicins E1 and E2}

Colicin E1 and E2 are Group A colicins and require the products of three genes sometimes known as cea (colicin E activity), imm (immunity), and lys (lysis protein). Here, we found variants of colicin E1 in isolates 0067K and 0143I on contigs with greatest identity to plasmids pCOLE1-H22 (from a 1978 Brazilian E. coli isolate [27]) and pEC276_KPC (GenBank: CP018949.1). The sequence of colicin E1 (and the associated immunity protein) found in isolate $0067 \mathrm{~K}$ deviated ( $86 \%$ and $92.9 \%$ aa identity, respectively) from the prototype cea and imm sequences (UniProtKB: PP02978 and P02985). To the best of our knowledge, cea in 0067K encodes a novel 'Colicin E', although similar sequences are found in the NCBI $n r$ database annotated as 'colicin 10' or 'colicin E1', despite lacking identity with the known sequence for colicin 10 (UniProtKB: Q47125) or colicin E1 (UniProtKB: P02978). The other colicin E1 detected in isolate 0143I was a near-identical variant ( $99.8 \%$ aa identity) to the colicin E1 prototype. In isolate $0089 \mathrm{~K}$, colicin E2 was found to be truncated and lacking the lys gene. However, the colicin E2 contig also encoded microcin J25 and the ESBL bla $a_{\mathrm{CTX}-\mathrm{M}-55}$, known to confer resistance to ceftazidime [28].

\subsubsection{Colicin V (Microcin)}

Colicin V was detected in isolates 0143I, 0114J, 0638J, 0315J, and 0089K. The synthesis of colicin V involves four genes: $c v a A, c v a B$ (a.k.a. $a p x l B, l t x B$, or $m c h F$ ), $c v a C$ (the colicin $\mathrm{V}$ activity gene, 103 a primary translation product), and the immunity gene, $c v i[29]$. We found $c v a C$ was identical to the prototype $c v a C$ (UniProtKB: P18002) in each isolate except for 0143I (72\% aa identity). Isolate 0143I lacked $c v a A$ and $c v a B$ elsewhere in the whole-genome sequence and was the only colicin V-containing isolate in which cvi was not identical to the known immunity gene sequence. Taken together, this 
suggest colicin V in $0143 \mathrm{I}$ is nonfunctional. In isolate $0114 \mathrm{~J}$, colicin V was co-located with colicin 1A on a contig aligning $(99.2 \%$ pairwise identity; $54.5 \%$ query coverage) with pCOV8, a colicin V-containing plasmid harbored by a commensal ESBL-producing E. coli isolated from the caecum of a broiler chicken in France [30]. The colicin V machinery in isolate 0315J was encoded on a contig aligning (100\% pairwise identity; $100 \%$ query coverage) to pCVM29188_146, a 146,811 bp plasmid encoding streptomycin, and tetracycline resistance genes. Plasmid pCVM29188_146 was originally found in a ceftiofur-resistant S. enterica subsp. enterica serovar Kentucky isolated from chicken meat. Interestingly, the $\sim 106 \mathrm{~kb}$ plasmid backbone of pCVM29188_146 is known to share $>90 \%$ nucleotide identity with two colicinogenic virulence plasmids from avian pathogenic E. coli (APEC) strains: pAPEC-O1-ColBM (encoding colicins B and M) and pAPEC-O2-ColV (encoding colicin V) [31].

\subsubsection{Microcin J25}

Microcin J25 is synthesized as a 58 a a precursor peptide encoded by $m j c A$. The mature microcin (21 aa) has a 'lasso' structure (an 8 aa cyclic portion and 13-residue linear segment that loops back through the cyclic segment) [32]. This structure inhibits transcription by directly obstructing nucleoside triphosphate (NTP) from entering RNA polymerase, acting as a 'cork in a bottle' [32]. The microcin is divergently transcribed with an operon containing genes $(m j c B, m j c C)$ involved in the maturation of the peptide, and $m j c D$, which serves the dual role of immunity and export [33]. Here, the microcin J25 cassette was detected in isolate $0089 \mathrm{~K}$ on a contig bearing the greatest resemblance $(99.7 \%$ nucleotide identity; $60.5 \%$ query coverage) to a large ( $>150 \mathrm{kbp}$ ) conjugative plasmid (GenBank: CP021198.1) from a clinical specimen isolated in China. In isolate $0089 \mathrm{~K}$, microcin $\mathrm{J} 25$ was co-located with a truncated remnant of colicin E2, which was likely nonfunctional.

\subsubsection{Microcin $\mathrm{H} 47$}

Microcin H47 and its associated genes were found in a single isolate, 0067K. Microcin H47 is encoded in a structure designated the 'microcin H47 small genomic island', a chromosomal $\sim 3 \mathrm{~kb}$ genetic system flanked by imperfect direct repeats. The microcin $\mathrm{H} 47$ small genomic island encodes all genes required for synthesis, post-translational modification, secretion, and immunity [34]. In strain $0067 \mathrm{~K}$, the entirety of the island was present with $93.9 \%$ nucleotide identity to the known sequence (GenBank: AJ009631.3). Microcin H47 is encoded by $m c h B$, encoding a 75 aa peptide. In isolate 0067K, $m c h B$ shared $100 \%$ a a identity with the prototype (UniProtKB: P62530), whereas the immunity protein, encoded by $m c h I$, shared $95.7 \%$ a $a$ identity with its prototype (UniProtKB: O86200). The small genomic island also harbors genes for microcin I47 and the cognate I47 immunity protein (mchS2 and mchS3, respectively). Microcin I47 has been found to be active under iron-limited conditions [34]. Consistent with the literature [34], the microcin $\mathrm{H} 47$ small genomic island in isolate $0067 \mathrm{~K}$ was located on a contig with high identity to chromosomal sequences, indicating it was not plasmid-borne.

\subsection{Activity against Shiga Toxin-Producing E. coli and Other Enteric Pathogens}

To assess the antimicrobial activity of each of the putative bacteriocin-producing strains identified in the initial screen, we further tested each isolate against an in-house collection of STEC $(n=8)$ and other enteric pathogens $(n=20)$ in the absence of mitomycin C. Isolate 0430J (colicin Ib) consistently inhibited multiple human- and bovine-derived isolates of STEC O157:H7, other STEC serotypes (O111, O121, O-26, O-45, O145, O103, and O178), and certain Yersinia spp. and Salmonella spp. (Figure 1A). Similarly, isolates 0114J (colicin V and colicin Ia) and 0096I (colicin Ia) were found to inhibit multiple E. coli STEC isolates and Salmonella spp., but not Yersinia spp. Overall, inhibition halos were not observed among test strains for most of the bacteriocin-producing E. coli identified. This suggests either the strains tested are resistant to most of the colicins and microcins tested, or these bacteriocins are not actively synthesized in the absence of induction with mitomycin C. Furthermore, none of the putative bacteriocin-producers inhibited other species tested, including Acinetobacter baumannii, 
Bacillus cereus, Pseudomonas aeruginosa, Staphylococcus aureus, Enterococcus faecium, Klebsiella pneumonia, and Campylobacter jejuni (data not shown).

\subsection{Activity of Bacteriocin-Producing E. coli against Antimicrobial Resistant Isolates from Bovines and Wastewater}

Each isolate in the E. coli collection was tested against every other isolate to assess their inhibitory activity against AMR E. coli in the absence of mitomycin C. This was done to identify additional putative bacteriocin-producing isolates. However, no additional putative producers were identified. Isolates 0430J, 0114J, 0096I, and 0089K were found to inhibit multiple isolates from the E. coli collection (Figure 1B), as did other putative bacteriocin-producing isolates (e.g., 0842J, 0043M, 0067K, and 0143I). Certain putative bacteriocin-producers were shown to be inhibited by other putative producers, but always encoded a different colicin and immunity protein. For example, isolates 0453J and 0430J, both harboring colicin Ib, were inhibited by isolate 0114J (colicins Ia and V). Isolate 0842K, harboring colicin R, was inhibited by producer isolates $0143 \mathrm{I}, 0114 \mathrm{~J}$, and $0089 \mathrm{~K}$, did not inhibit any of the known bacteriocin-producing E. coli, but otherwise inhibited 'non-producer' isolates 0008F, 008M, 0053J, 0143K, and 0638J. Of the 90 isolates, only 9 were not inhibited by any other isolate. To determine if the AMR phenotype was correlated with resistance to putative bacteriocin producer, Spearman's rank-order was performed and identified no significant correlations between the AMR resistance profile and resistance to any of the bacteriocin-producing strains.

2.5. Effectiveness of Bacteriocin-Producers in Broth-Based Competitions with E. coli K-12 Strain MG1655 or the Shiga Toxin-Producing E. coli Strain EDL933

Many of the putative bacteriocin-producers identified here did not exhibit activity against multiple E. coli under the conditions of the agar-based inhibition halo assay. Although isolates were treated with mitomycin $C$ in the initial screen for putative bacteriocin-producing bacteria [4], mitomycin $C$ was not used competition assays because one of the objectives of this work was to identify putative bacteriocin producers capable of inhibiting AMR E. coli without induction (i.e., constitutively expressed/secreted bacteriocins). To assess how putative bacteriocin producers might act in liquid culture in a competitive growth curve, luciferase-expressing E. coli K-12 strain MG1655 and O157:H7 strain EDL933 (pAKux2; ampicillin-resistant) were competed with the putative bacteriocin-producers, with light production monitored continuously for $12 \mathrm{~h}$ (Figure 4A). An OD-based growth curve of each putative bacteriocin-producing strain and the luciferase-expressing strains was taken to ensure each strain had comparable growth rates (Figure 4B). Likewise, CFU were enumerated at $0 \mathrm{hr}$ and $12 \mathrm{hr}$ on agar supplemented with ampicillin to assess viability of MG1655/pAKlux2 or EDL933/pAKlux2, following co-culture with the bacteriocin-producer isolates (Figure 4C).

Via these methods, the isolates harboring bacteriocin genes decreased light production from MG1655/pAKlux2 co-cultures, lowering both the maximum detectable light production throughout the time course and at the endpoint (12 h) (Figure 4A, upper panel), an inhibitory response that corresponded to the agar-based method. The control for these experiments was an equivalent co-culture of MG1655 with MG1655/pAKlux2. All bacteriocin-producers prevented growth of MG1655/pAKlux2 to lower levels compared to the control co-culture or resulted in log-fold decreases in MG1655/pAKlux2 viability (Figure 4C). Likewise, all putative bacteriocin-producers exhibited inhibition of EDL933/pAKlux2 (Figure 4A, lower panel), contradictory to results with the agar-based assay (Figure 1A) This trend was generally reflected in the viable CFU counts (Figure 4 C), in which most of the putative bacteriocin-producers, excluding isolates 0842J, 0043M, and 0067K, caused log-fold decreases in viability of strain EdL933. All putative bacteriocin-producers inhibited growth of EDL933/pAKlux2 as compared to the EDL933 and EDL933/pAKlux2 co-culture control. These results suggest putative bacteriocin-producers could be more effective against susceptible E. coli under specific conditions. These data also demonstrated that co-culture with luciferase-expressing E. coli may be a more rapid methodology for screening larger isolate libraries for antimicrobial activity. 
A

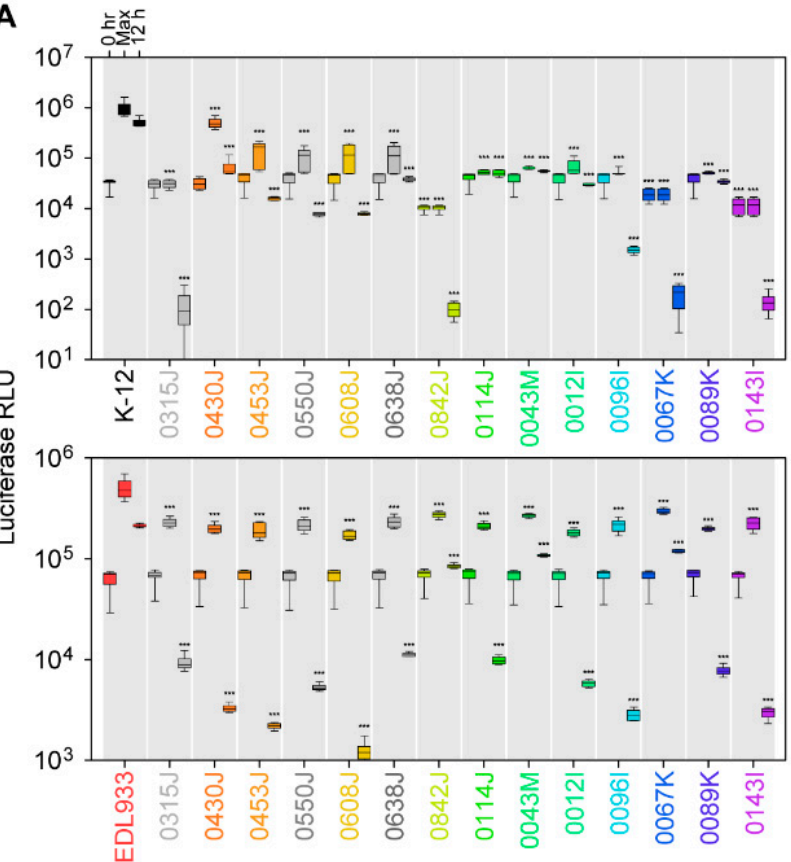

B
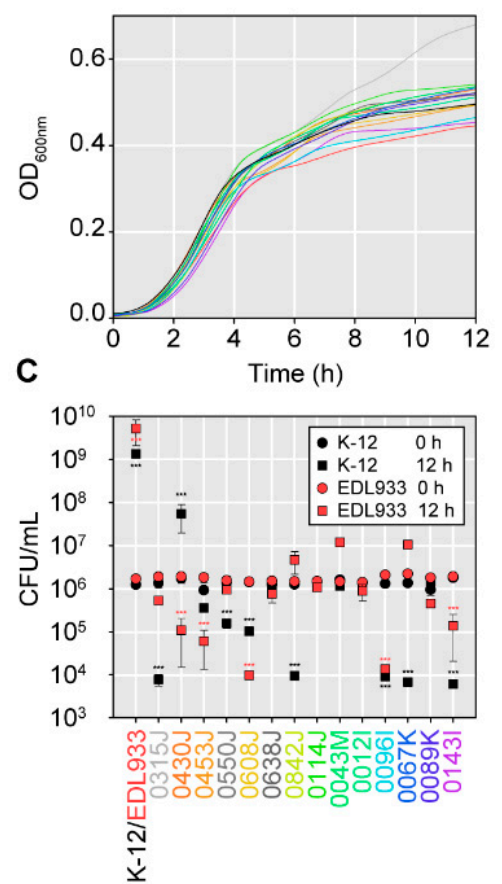

Figure 4. Co-culture broth-based competitions between bacteriocin-producing isolates and indicator luciferase-expressing E. coli K-12 strain MG1655/pAKlux2 and E. coli O157:H7 strain EDL933/pAKlux2. (A) Upper panel: OD-equivalent co-culture of putative bacteriocin-producers or E. coli MG1655 with MG1655/pAKlux2. Lower panel: Co-culture with EDL933/pAKlux2. Data shown are log-scale luminometric relative light units (RLU) with initial, maximal, and endpoint measurements shown for a $12 \mathrm{~h}$ time course. Mean of 12 biological replicates; error bars indicate SEM. (B) Growth-curves $\left(12 \mathrm{~h} ; \mathrm{OD}_{600 \mathrm{~nm}}\right)$ of bacteriocin-producing isolate monocultures. No significant differences in growth rate were observed between isolates and E. coli MG1655/pAKlux2 or EDL933/pAKlux2. (C) CFU (ampicillin-resistant) recovered from co-culture competitions at $0 \mathrm{~h}$ and $12 \mathrm{~h}$ timepoints. Data shown are the mean of three biological replicates; error bars indicate SEM. Statistical tests are one-way ANOVAs; $P$-value summary: * $(P \leq 0.05) ;{ }^{* *}(P \leq 0.01) ;{ }^{* * *}(P \leq 0.001)$.

\section{Discussion}

In this investigation, we performed an initial screen to identify E. coli isolates capable of producing diffusible substances inhibiting generic and AMR E. coli, STEC, and other enteric pathogens, and identified a variety of known genes coding for bacteriocins through whole-genome sequencing. One isolate potentially harbored up to four bacteriocin genes, a finding in agreement with research suggesting E. coli encoding more than one type of bacteriocin are relatively prevalent [4]. An obvious advantage of producing multiple bacteriocins is a wider spectrum of activity against competing bacteria, a wider receptor repertoire, and theoretically, enhanced fitness in more environments [35]. Putative bacteriocin-producers were found to be capable of inhibiting AMR bacteria and some producers inhibited numerous E. coli. However, our data highlighted some of the issues confounding both the identification and the effective application of bacteriocin-producers as alternative antimicrobials. These include: (i) Most putative bacteriocin producers identified here did not inhibit E. coli under the conditions of the agar-based assay, despite producing diffusible substances with antimicrobial activity under mitomycin $\mathrm{C}$ induction; (ii) in some instances, putative bacteriocin-producers with no apparent antimicrobial activity in the agar-based assay exhibited activity in the liquid luciferase-based assay; (iii) although some of the isolates produced log-scale decreases in viability in the target E. coli, none completely eliminated either generic E. coli K12 or STEC EDL933 when in co-culture; and (iv) these methods do not exclude other factors contributing in-whole or in-part to inhibition in 
co-culture assays. Other confounding variables include non-expression or incomplete maturation of the putative bacteriocins in different growth phases and culture conditions, and similar changes affecting susceptibility of the target population [25]. Putative bacteriocin-producers are likely to harbor other competitive mechanisms responsible for discrepancies between solid and liquid-based assays (e.g., contact-dependent growth inhibition [5]). Furthermore, the ecology of natural environments is more complicated than a two-strain competition. Although targeted bacteria may be initially reduced in natural environments, susceptible populations are likely to undergo post-exposure recovery. Constant exposure to bacteriocin-producers may overcome this limitation, provided the strain is fit and remains viable in the environment of interest. Based on current understanding of how certain colicins and microcins are produced and regulated, it is likely these issues will persist in isolates selected for development as probiotics.

Some putative bacteriocinogenic isolates identified here were notable for phenotypic resistance to up to nine antimicrobials. Although we do not envision these particular isolates being directly developed as probiotics, the fact remains that bacteriocin-producers are not suitable probiotics if they harbor AMR genes or other virulence determinants. Although bacteriocins may be desirable features of probiotics, bacteriocin production is also a desirable trait for pathogenic bacteria [16].

Given that most of the bacteriocins identified in this study are hosted on self-transmissible plasmids, it would seem to be folly to use them against AMR bacteria if those same bacteria could easily acquire the bacteriocin and its cognate immunity gene. This would simply be recapitulating the problem of increasing AMR. This suggests purification (i.e., divorcing the bacteriocin from its immunity gene) is the way forward with bacteriocin development, a much more complicated endeavor than live probiotic administration. Work with purified microcin $\mathrm{J} 25$ has been found to be effective in a mouse model of infection, reducing viable counts of Salmonella Newport in the spleen and liver by 2-3 logs compared to peptide-free controls [36]. Likewise, dietary supplementation of microcin J25 improved performance and attenuated diarrhea in weaned pigs [37]. This demonstrates the therapeutic potential of bacteriocins. Therefore, it is important to continue identifying novel bacteriocins or variants for potential downstream development. Future work using strains/plasmids constructed with each of the bacteriocin-encoding loci independently is required to elucidate the effects of each of the putative bacteriocins identified here. Another drawback of the work presented here is that in silico identification generally relies on prior knowledge of bacteriocin sequences. As a result, our study did not identify novel bacteriocins. Furthermore, we only sequenced putative bacteriocin-producing isolates here, but understanding why certain isolates are resistant to putative bacteriocin producers is important if bacteriocins are to be useful as probiotics. Such strains might harbor bacteriocin immunity genes without the cognate bacteriocin, as we observed here in several instances, or other resistance mechanisms, such as outer membrane modifications [23].

Collectively, the results here demonstrate the complexity associated with identifying bona fide bacteriocin production and activity using putative bacteriocin-producers and susceptible E. coli. Although we initially used mitomycin $C$ to induce bacteriocin production, it is not feasible to use mitomycin $C$ in most downstream applications, such as in conjunction with probiotic administration to promote bacteriocin production in vivo. Consequently, we chose not to use mitomycin $\mathrm{C}$ when screening for putative bacteriocin-producers, hoping to identify isolates constitutively exerting antimicrobial activity. This putatively identified isolates 0096I and 0430J as meeting this criterion, which harbored variants of colicin Ia and colicin Ib, respectively. This result was confounded by other isolates, which contained colicin Ia and colicin $\mathrm{Ib}$ (and other bacteriocins) and did not exhibit the same activity between the agar-based assay and the luciferase-based assay. Furthermore, some isolates possessed the same colicin, but exhibited varying activity, as was the case with 430J and 453J, where both possessed colicin $\mathrm{Ib}$, but only 430J inhibited multiple E. coli strains. Some possible explanations for this discrepancy include: (i) Variations in the colicin aa sequence confer different antimicrobial activity or different receptor binding and uptake capabilities; (ii) producer-specific peculiarities alter colicin production; and (iii) unknown defense mechanisms. Some evidence here suggests the latter 
might be more likely. For example, isolate $0453 \mathrm{~J}$, putatively produced colicin Ib that exhibited no activity against EDL933 in the agar-based assay, yet was effective in liquid competition, and inhibited EDL933/pAKlux2 in the luciferase-based assay, decreasing viability as demonstrated by a decline in CFU. Collectively, these data suggest luciferase-expressing E. coli used in competitive assays could be a rapid, but limited methodology for detecting putative bacteriocinogenic isolates and antimicrobial activity. Such luciferase-based competition screens have been deployed elsewhere [38]. The value of this method is sensitivity, the ability to observe the kinetics of a co-culture competition, and most significantly, the ability to screen hundreds of isolates simultaneously. However, the broth- and luciferase-based systems have several disadvantages compared to the agar-based assay, including: (i) The inability to distinguish between inhibition due to bacteriophages; (ii) unknown effects of luciferase expression on cell viability; and (iii) the inability to distinguish inhibition due to diffusible substances vs. inhibition due to other factors. In conclusion, we identified a number of putative bacteriocinogenic isolates capable of inhibiting AMR E. coli and STEC with diffusible products and demonstrated the utility of a luciferase-based assay for future screens for bacteriocin-producers.

\section{Materials and Methods}

\subsection{Enrichment and Isolation of E. coli}

E. coli were isolated from bovine feces, beef cattle feedlot catchbasins, and community wastewater in Alberta, Canada as similarly described [39]. Briefly, putative E. coli were enriched in Nutrient Broth (NB) supplemented with $2 \mu \mathrm{g} / \mathrm{mL}$ cefotaxime (MilliporeSigma, Etobicoke, ON, Canada) (grown overnight at $37^{\circ} \mathrm{C}$ shaking). Enrichments were plated for isolation on MacConkey agar containing $4 \mu \mathrm{g} / \mathrm{mL}$ cefoxitin (MilliporeSigma) and lactose-fermenting colonies were further isolated on tryptic soy agar (TSA) supplemented with $4 \mu \mathrm{g} / \mathrm{mL}$ cefoxitin. All media were BD Difco or BBL products (ThermoFisher, Burlington, ON, Canada). E. coli were confirmed with $16 \mathrm{~S}$ rRNA sequencing and for indole production (Kovacs reagent; Fisher Scientific, Pittsburgh, PA, USA) as previously described.

\subsection{Screening for Bacteriocin Production and Activity against Enteric Bacteria}

A library of 90 confirmed E. coli was arrayed by inoculation into 96-well microplates containing $200 \mu \mathrm{L}$ of Mueller-Hinton (MH) II broth. MH was chosen because of its routine use in antimicrobial susceptibility testing. Bacterial growth at $37^{\circ} \mathrm{C}$ was monitored by spectrophotometry (BioTek HTX Synergy plate reader) to an $\mathrm{OD}_{600 \mathrm{~nm}}$ of $\sim 0.2$ then diluted $1 / 100$ into fresh $\mathrm{MH}$ broth containing $0.2 \mu \mathrm{g} / \mathrm{mL}$ mitomycin C (MilliporeSigma) in a new 96-well plate and incubated for $1 \mathrm{~h}$. To test for activity against non-pathogenic or Shiga toxin-producing E. coli (STEC), $5 \mu \mathrm{L}$ from each well was spotted onto a single-well microplate containing $\mathrm{MH}$ agar recently inoculated either with $0.005 \mathrm{OD}_{600 \mathrm{~nm}}$ of $E$. coli K-12 (strain MG1655) or E. coli O157:H7 strain EDL933, a well-characterized enterohaemorrhagic STEC. Plates were incubated at $37^{\circ} \mathrm{C}$ for $18 \mathrm{~h}$ and then imaged using the BIOMIC V3 Microbiology System (Giles Scientific). Inhibition halos in underlying E. coli lawns were measured with ImageJ (NIH). The arrayed library was likewise tested for activity against each isolate present in the library to further identify bacteriocin-producing E. coli, and to assess their capacity to inhibit $E$. coli with known antimicrobial susceptibility profiles. Isolates capable of inhibiting any E. coli strain were selected for additional testing against an in-house collection of STEC of human or bovine-origin (O157, O26, O45, O103, O111, O121, O145, O178) [40] and other bacterial species, including Acinetobacter baumannii (ATCC 17978), Bacillus cereus (ATCC 14579), Campylobacter jejuni (ATCC 33560), Clostridium difficile (ATCC 9689), Enterococcus faecium (ATCC 19434), Klebsiella pneumonia (ATCC 700603), Klebsiella pneumoniae (ATCC 4352), Listeria monocytogenes (ATCC 19117), Pseudomonas aeruginosa (ATCC 27853), Salmonella enterica (Braenderup), Salmonella enterica Enteritidis (ATCC 13076), Salmonella enterica paratyphi (ATCC 9150), Salmonella typhimuriam (ATCC 13311), Staphylococcus aureus (ATCC 25923), Staphylococcus aureus (ATCC 29213), Staphylococcus aureus (ATCC 29740), Staphylococcus aureus (ATCC 35556), Streptococcus pneumonia (ATCC 33400), Yersinia enterocolitica (ATCC 9610), and Yersinia pseudotuberculosis (ATCC 
6904). In brief, bacterial lawns were swabbed on $\mathrm{MH}$ agar from a bacterial suspension standardized to $\sim \mathrm{OD}_{600 \mathrm{~nm}} 0.1$ in sterile saline. Next, $5 \mu \mathrm{L}\left(\mathrm{OD}_{600 \mathrm{~nm}} 0.005\right)$ of bacteriocin-producers was spotted onto the agar surface, and inhibition halos were measured following growth for $20 \mathrm{~h}$ at $37^{\circ} \mathrm{C}$. Bacteriophage vs. bacteriocin production was differentiated as described elsewhere [41]. Essentially, inhibitory activity due to diffusible substances was assessed by serial dilution of supernatants from cultures of putative bacteriocin-producers on lawns of E. coli K-12 and confirmed negative for the presence of phage plaques.

\subsection{Antimicrobial Susceptibility Assays}

Disc-based susceptibility testing was performed using CLSI guidelines (CLSI document M02-A12 and CLSI supplement M100S) [42,43]. E. coli isolates were tested for resistance to oxytetracycline, trimethoprim/sulfamethoxazole, ampicillin, florfenicol (Oxoid), neomycin, sulfisoxazole, streptomycin, ceftiofur (Oxoid), ceftazidime, and amoxicillin/clavulanate. Unless otherwise indicated, all tests were conducted with BD BBL Sensi-Disc antimicrobial susceptibility test discs (BD). Zones of inhibition were measured using the BioMic V3 imaging system (Giles Scientific, Santa Barbara, CA, USA). Except for neomycin, which used EUCAST criteria (www.eucast.org), CLSI criteria [42,43] was used to categorize isolates as 'sensitive' or 'resistant'. Here, 'intermediate' resistance was designated as 'sensitive'.

\subsection{Broth-Based Co-culture and Activity Assay with Luciferase-Expressing E. coli}

E. coli K-12 strain MG1655 and E. coli O157:H7 strain EDL933 were electroporated with the luciferase-expressing plasmid pAKlux2 [44] (ampicillin-resistant) and recovered on LB agar supplemented with $100 \mu \mathrm{g} / \mathrm{mL}$ ampicillin. Light production was confirmed in selected colonies using a FluorChem HD2 (Alpha Innotech). To assess inhibition in broth culture, light production was measured repeatedly in OD-equivalent $200 \mu \mathrm{L} \mathrm{MH}$ broth (without antimicrobials) co-cultures of either MG1655/pAKlux2 or EDL933/pAKlux2 (at OD $600 \mathrm{~nm}$ 0.005) and bacteriocin-producers $\left(\mathrm{OD}_{600 \mathrm{~nm}} 0.005\right.$; total initial $\mathrm{OD}_{600 \mathrm{~nm}} 0.01$ in all tests and growth curves) in black clear-bottom 96-well plates (Nunc) using luminometry (BioTek HTX Synergy plate reader). Inhibition was registered as decreased light emission compared to control co-cultures, where either MG1655 or EDL933 (without pAKlux2) were equivalently inoculated with the luciferase-expressing version. For CFU-based co-culture experiments, CFU were enumerated on MH supplemented with $100 \mu \mathrm{g} / \mathrm{mL}$ of ampicillin.

\subsection{Whole-Genome Sequencing and Bioinformatic Identification of Bacteriocin Genes}

To characterize putative bacteriocin-producers, select isolates (those inhibiting MG1655 or EDL933 under mitomycin C exposure) were whole-genome sequenced. Briefly, DNA was extracted (DNeasy Blood and Tissue kit, Qiagen, Germantown, MD, USA) from E. coli cultured on BHI agar plates and prepared for Illumina MiSeq $2 \times 300$ paired-end sequencing at the Canadian Food Inspection Agency Lethbridge Laboratory. Trimmomatic 0.38 was used to trim reads and the Illumina adaptors with criteria: phred33, LEADING:3, TRAILING:3, SLIDINGWINDOW:4:15, MINLEN:36. SPAdes 3.13.0. [45] and PROKKA [46] were used for contig assembly and annotation, respectively. To identify bacteriocins in silico, contigs were searched for hits aligning (blastx in Geneious 8.1.9) with 230 bacteriocins downloaded from BACTIBASE [47]. Hits with $>30 \%$ pairwise $a a$ identity were retained and scrutinized manually for co-localization with other bacteriocins and immunity protein homologues, which were further identified in adjacent ORFs using NCBI CD search (NIH) [48]. Sequences from putative bacteriocin-producers were assessed with BAGEL3 for comparison [49]. 


\subsection{Data Visualization and Statistical Analyses}

For pairwise sequence comparisons, bacteriocin and immunity genes were translated (bacterial transl_table 11) and aligned with MUSCLE (default parameters) in Geneious 8.1.9. Interactions between bacteriocin-producers and susceptible E. coli were visualized with Circos [50]. Gene diagrams and alignment identities were produced in EasyFig [51]. All statistical tests were one-way ANOVAs (multiple comparisons vs. control group; Bonferroni t-test) performed in Sigmaplot 13.0 (Systat Software Inc.). $P$-value summary: Not significant $(P>0.05) ;{ }^{*}(P \leq 0.05) ;{ }^{* *}(P \leq 0.01) ;{ }^{* * *}(P \leq 0.001)$. Error bars indicate standard error of the mean (SEM).

\subsection{Nucleotide Sequence Accession Numbers}

Bacteriocin-containing contig sequences were deposited in GenBank under accession numbers MK878515 to MK878535. Illumina sequence data were deposited in the NCBI Short Read Archive under BioProject ID PRJNA556083.

Author Contributions: Conceptualization, A.C. and T.A.M.; Methodology, A.C., R.Z.; Software, A.C., R.Z.; Validation, A.C., R.Z.; Formal Analysis, A.C., R.Z.; Investigation, A.C., R.B., E.H.A., R.Z.; Resources, T.R., T.A.M.; Data Curation, A.C., R.B., R.Z.; Writing-Original Draft Preparation, A.C.; Writing-Review \& Editing, A.C., R.B., E.H.A.; R.Z., T.R., T.A.M.; Visualization, A.C.; Supervision, T.A.M.; Project Administration, T.A.M.; Funding Acquisition, T.A.M.

Funding: This research was funded by Alberta Agriculture and Forestry Strategic Research and Development and the Beef Cattle Research Council (BCRC) - Agriculture and Agri-Food Canada beef cluster. A.C. is supported by an NSERC Postdoctoral Fellowship.

Acknowledgments: We thank Reuben Ha, Cheyenne Conrad, Shaun Cook, and Wendi Smart for laboratory assistance and maintenance.

Conflicts of Interest: The funders had no role in the design of the study; in the collection, analyses, or interpretation of data; in the writing of the manuscript, or in the decision to publish the results.

\section{References}

1. Flaherty, R.A.; Freed, S.D.; Lee, S.W. The wide world of ribosomally encoded bacterial peptides. PLoS Pathog. 2014, 10, e1004221. [CrossRef] [PubMed]

2. Cascales, E.; Buchanan, S.K.; Duché, D.; Kleanthous, C.; Lloubes, R.; Postle, K.; Riley, M.; Slatin, S.; Cavard, D. Colicin biology. Microbiol. Mol. Biol. Rev. 2007, 71, 158-229. [CrossRef] [PubMed]

3. Destoumieux-Garzón, D.; Peduzzi, J.; Rebuffat, S. Focus on modified microcins: Structural features and mechanisms of action. Biochimie 2002, 84, 511-519. [CrossRef]

4. Gordon, D.M.; O'Brien, C.L. Bacteriocin diversity and the frequency of multiple bacteriocin production in Escherichia coli. Microbiology 2006, 152, 3239-3244. [CrossRef] [PubMed]

5. Paquette, S.-J.; Zaheer, R.; Stanford, K.; Thomas, J.; Reuter, T. Competition among Escherichia coli strains for space and resources. Veter. Sci. 2018, 5, 93. [CrossRef] [PubMed]

6. Nolan, E.M.; Walsh, C.T. Investigations of the MceIJ-catalyzed posttranslational modification of the microcin E492 C-terminus: Linkage of ribosomal and nonribosomal peptides to form "trojan horse" antibiotics. Biochemistry 2008, 47, 9289-9299. [CrossRef] [PubMed]

7. Lazzaroni, J.-C.; Dubuisson, J.-F.; Vianney, A. The Tol proteins of Escherichia coli and their involvement in the translocation of group A colicins. Biochimie 2002, 84, 391-397. [CrossRef]

8. Suit, J.L.; Fan, M.-L.J.; Sabik, J.F.; Labarre, R.; Luria, S. Alternative forms of lethality in mitomycin C-induced bacteria carrying ColE1 plasmids. Proc. Natl. Acad. Sci. USA 1983, 80, 579-583. [CrossRef]

9. Azpiroz, M.F.; Laviña, M. Modular structure of microcin H47 and colicin V. Antimicrob. Agents Chemother. 2007, 51, 2412-2419. [CrossRef]

10. Dobson, A.; Cotter, P.D.; Ross, R.P.; Hill, C. Bacteriocin production: A probiotic trait? Appl. Environ. Microbiol. 2012, 78, 1-6. [CrossRef] 
11. Schamberger, G.P.; Diez-Gonzalez, F. Characterization of colicinogenic Escherichia coli strains inhibitory to enterohemorrhagic Escherichia coli. J. Food Prot. 2004, 67, 486-492. [CrossRef] [PubMed]

12. Wisener, L.; Sargeant, J.; O'connor, A.; Faires, M.; Glass-Kaastra, S. The use of direct-fed microbials to reduce shedding of Escherichia coli $\mathrm{O} 157$ in beef cattle: A systematic review and meta-analysis. Zoonoses Public Health 2015, 62, 75-89. [CrossRef] [PubMed]

13. Lagha, A.B.; Haas, B.; Gottschalk, M.; Grenier, D. Antimicrobial potential of bacteriocins in poultry and swine production. Veter. Res. 2017, 48, 22. [CrossRef] [PubMed]

14. Zmora, N.; Zilberman-Schapira, G.; Suez, J.; Mor, U.; Dori-Bachash, M.; Bashiardes, S.; Kotler, E.; Zur, M.; Regev-Lehavi, D.; Brik, R.B.-Z. Personalized gut mucosal colonization resistance to empiric probiotics is associated with unique host and microbiome features. Cell 2018, 174, 1388-1405. [CrossRef] [PubMed]

15. Cotter, P.D.; Hill, C.; Ross, R.P.; Ross, R. Bacteriocins: Developing innate immunity for food. Nat. Rev. Genet. 2005, 3, 777-788. [CrossRef] [PubMed]

16. Šmajs, D.; Micenková, L.; Šmarda, J.; Vrba, M.; Ševčíková, A.; Vališová, Z.; Woznicová, V. Bacteriocin synthesis in uropathogenic and commensal Escherichia coli: Colicin E1 is a potential virulence factor. BMC Microbiol. 2010, 10, 288. [CrossRef] [PubMed]

17. Gillor, O.; Etzion, A.; Riley, M. The dual role of bacteriocins as anti-and probiotics. Appl. Microbiol. Biotechnol. 2008, 81, 591-606. [CrossRef] [PubMed]

18. Hegarty, J.W.; Guinane, C.M.; Ross, R.P.; Hill, C.; Cotter, P.D. Bacteriocin production: A relatively unharnessed probiotic trait? F1000Research 2016, 5, 2587. [CrossRef] [PubMed]

19. Rodriguez-Bano, J.; Gutierrez-Gutierrez, B.; Machuca, I.; Pascual, A. Treatment of infections caused by extended-spectrum-beta-lactamase-, AmpC-, and carbapenemase-producing Enterobacteriaceae. Clin. Microbiol. Rev. 2018, 31, e00079-17. [CrossRef] [PubMed]

20. Oteo, J.; Pérez-Vázquez, M.; Campos, J. Extended-spectrum $\beta$-lactamase producing Escherichia coli: Changing epidemiology and clinical impact. Curr. Opin. Infect. Dis. 2010, 23, 320-326. [CrossRef] [PubMed]

21. Sperandio, V.; Hovde, C.J. Enterohemorrhagic Escherichia coli and Other Shiga Toxin-Producing E. coli; American Society for Microbiology (ASM): Washington, DC, USA, 2015.

22. Hussein, H. Prevalence and pathogenicity of Shiga toxin-producing Escherichia coli in beef cattle and their products. J. Anim. Sci. 2007, 85, E63-E72. [CrossRef] [PubMed]

23. Gordon, D.M.; Oliver, E.; Littlefield-Wyer, J. The diversity of bacteriocins in Gram-negative bacteria. In Bacteriocins; Springer: Berlin, Germany, 2007; pp. 5-18.

24. El Ghachi, M.; Bouhss, A.; Barreteau, H.; Touzé, T.; Auger, G.; Blanot, D.; Mengin-Lecreulx, D. Colicin M exerts its bacteriolytic effect via enzymatic degradation of undecaprenyl phosphate-linked peptidoglycan precursors. J. Biol. Chem. 2006, 281, 22761-22772. [CrossRef] [PubMed]

25. Zschüttig, A.; Auerbach, C.; Meltke, S.; Eichhorn, C.; Brandt, M.; Blom, J.; Goesmann, A.; Jarek, M.; Scharfe, M.; Zimmermann, K. Complete sequence of probiotic symbioflor 2 Escherichia coli strain G3/10 and draft sequences of symbioflor 2 E. coli strains G1/2, G4/9, G5, G6/7, and G8. Genome Announc. 2015, 3, e01330-14. [CrossRef] [PubMed]

26. Rendueles, O.; Beloin, C.; Latour-Lambert, P.; Ghigo, J.-M. A new biofilm-associated colicin with increased efficiency against biofilm bacteria. ISME J. 2014, 8, 1275. [CrossRef] [PubMed]

27. Cursino, L.; Šmajs, D.; Šmarda, J.; Nardi, R.; Nicoli, J.; Chartone-Souza, E.; Nascimento, A. Exoproducts of the Escherichia coli strain $\mathrm{H} 22$ inhibiting some enteric pathogens both in vitro and in vivo. J. Appl. Microbiol. 2006, 100, 821-829. [CrossRef] [PubMed]

28. Yang, Q.E.; Walsh, T.R.; Liu, B.T.; Zou, M.T.; Deng, H.; Fang, L.X.; Liao, X.P.; Sun, J.; Liu, Y.H. Complete sequence of the FII plasmid p42-2, carrying blaCTX-M-55, oqxAB, fos A3, and floR from Escherichia coli. Antimicrob. Agents Chemother. 2016, 60, 4336-4338. [CrossRef] [PubMed]

29. Gilson, L.; Mahanty, H.K.; Kolter, R. Genetic analysis of an MDR-like export system: The secretion of colicin V. EMBO J. 1990, 9, 3875-3884. [CrossRef] [PubMed]

30. Touzain, F.; Le Devendec, L.; De Boisseson, C.; Baron, S.; Jouy, E.; Perrin-Guyomard, A.; Blanchard, Y.; Kempf, I. Characterization of plasmids harboring blaCTX-M and blaCMY genes in E. coli from French broilers. PLoS ONE 2018, 13, e0188768. [CrossRef] [PubMed] 
31. Fricke, W.F.; McDermott, P.F.; Mammel, M.K.; Zhao, S.; Johnson, T.J.; Rasko, D.A.; Fedorka-Cray, P.J.; Pedroso, A.; Whichard, J.M.; LeClerc, J.E. Antimicrobial resistance-conferring plasmids with similarity to virulence plasmids from avian pathogenic Escherichia coli strains in Salmonella enterica serovar Kentucky isolates from poultry. Appl. Environ. Microbiol. 2009, 75, 5963-5971. [CrossRef]

32. Mukhopadhyay, J.; Sineva, E.; Knight, J.; Levy, R.M.; Ebright, R.H. Antibacterial peptide microcin J25 inhibits transcription by binding within and obstructing the RNA polymerase secondary channel. Mol. Cell 2004, 14, 739-751. [CrossRef]

33. Bountra, K.; Hagelueken, G.; Choudhury, H.G.; Corradi, V.; El Omari, K.; Wagner, A.; Mathavan, I.; Zirah, S.; Wahlgren, W.Y.; Tieleman, D.P. Structural basis for antibacterial peptide self-immunity by the bacterial ABC transporter McjD. EMBO J. 2017, 36, 3062-3079. [CrossRef] [PubMed]

34. Azpiroz, M.F.; Bascuas, T.; Laviña, M. Microcin H47 system: An Escherichia coli small genomic island with novel features. PLoS ONE 2011, 6, e26179. [CrossRef] [PubMed]

35. Czárán, T.L.; Hoekstra, R.F.; Pagie, L. Chemical warfare between microbes promotes biodiversity. Proc. Natl. Acad. Sci. USA 2002, 99, 786-790. [CrossRef] [PubMed]

36. Lopez, F.E.; Vincent, P.A.; Zenoff, A.M.; Salomon, R.A.; Farías, R.N. Efficacy of microcin J25 in biomatrices and in a mouse model of Salmonella infection. J. Antimicrob. Chemother. 2007, 59, 676-680. [CrossRef] [PubMed]

37. Yu, H.; Ding, X.; Li, N.; Zhang, X.; Zeng, X.; Wang, S.; Liu, H.; Wang, Y.; Jia, H.; Qiao, S. Dietary supplemented antimicrobial peptide microcin $\mathrm{J} 25$ improves the growth performance, apparent total tract digestibility, fecal microbiota, and intestinal barrier function of weaned pigs. J. Anim. Sci. 2017, 95, 5064-5076. [CrossRef] [PubMed]

38. El Kheir, S.M.; Cherrat, L.; Awussi, A.A.; Ramia, N.E.; Taha, S.; Rahman, A.; Passerini, D.; Leroi, F.; Petit, J.; Mangavel, C. High-throughput identification of candidate strains for biopreservation by using bioluminescent Listeria monocytogenes. Front. Microbiol. 2018, 9, 9. [CrossRef] [PubMed]

39. Mollenkopf, D.F.; Weeman, M.F.; Daniels, J.B.; Abley, M.J.; Mathews, J.L.; Gebreyes, W.A.; Wittum, T.E. Variable within-and between-herd diversity of CTX-M cephalosporinase-bearing Escherichia coli isolates from dairy cattle. Appl. Environ. Microbiol. 2012, 78, 4552-4560. [CrossRef] [PubMed]

40. Stanford, K.; Johnson, R.P.; Alexander, T.W.; McAllister, T.A.; Reuter, T. Influence of season and feedlot location on prevalence and virulence factors of seven serogroups of Escherichia coli in feces of western-Canadian slaughter cattle. PLoS ONE 2016, 11, e0159866. [CrossRef] [PubMed]

41. Hockett, K.L.; Baltrus, D.A. Use of the soft-agar overlay technique to screen for bacterially produced inhibitory compounds. J. Vis. Exp. 2017, 119, e55064. [CrossRef]

42. CLSI. Performance standards for antimicrobial disk susceptibility tests; approved standard twelfth edition. In CLSI Document M02-A12; Clinical and Laboratory Standards Institute: Wayne, PA, USA, 2015; Volume CLSI document M02-A12.

43. CLSI. Performance standards for antimicrobial susceptibility testing. In CLSI supplement M100S, 26th ed.; Clinical and Laboratory Standards Institute: Wayne, PA, USA, 2016.

44. Karsi, A.; Lawrence, M.L. Broad host range fluorescence and bioluminescence expression vectors for Gram-negative bacteria. Plasmid 2007, 57, 286-295. [CrossRef]

45. Bankevich, A.; Nurk, S.; Antipov, D.; Gurevich, A.A.; Dvorkin, M.; Kulikov, A.S.; Lesin, V.M.; Nikolenko, S.I.; Pham, S.; Prjibelski, A.D. SPAdes: A new genome assembly algorithm and its applications to single-cell sequencing. J. Comput. Boil. 2012, 19, 455-477. [CrossRef] [PubMed]

46. Seemann, T. Prokka: Rapid prokaryotic genome annotation. Bioinformatics 2014, 30, 2068-2069. [CrossRef] [PubMed]

47. Hammami, R.; Zouhir, A.; Le Lay, C.; Ben Hamida, J.; Fliss, I. BACTIBASE second release: A database and tool platform for bacteriocin characterization. BMC Microbiol. 2010, 10, 22. [CrossRef] [PubMed]

48. Marchler-Bauer, A.; Bo, Y.; Han, L.; He, J.; Lanczycki, C.J.; Lu, S.; Chitsaz, F.; Derbyshire, M.K.; Geer, R.C.; Gonzales, N.R.; et al. CDD/SPARCLE: Functional classification of proteins via subfamily domain architectures. Nucleic Acids Res. 2016, 45, D200-D203. [CrossRef] [PubMed]

49. van Heel, A.J.; de Jong, A.; Montalban-Lopez, M.; Kok, J.; Kuipers, O.P. BAGEL3: Automated identification of genes encoding bacteriocins and (non-) bactericidal posttranslationally modified peptides. Nucleic Acids Res. 2013, 41, W448-W453. [CrossRef] [PubMed] 
50. Krzywinski, M.; Schein, J.; Birol, I.; Connors, J.; Gascoyne, R.; Horsman, D.; Jones, S.J.; Marra, M.A. Circos: An information aesthetic for comparative genomics. Genome Res. 2009, 19, 1639-1645. [CrossRef] [PubMed]

51. Sullivan, M.J.; Petty, N.K.; Beatson, S.A. Easyfig: A genome comparison visualizer. Bioinformatics 2011, 27, 1009-1010. [CrossRef]

(C) 2019 by the authors. Licensee MDPI, Basel, Switzerland. This article is an open access article distributed under the terms and conditions of the Creative Commons Attribution (CC BY) license (http://creativecommons.org/licenses/by/4.0/). 